Tempo Social; Rev. Sociol. USP, S. Paulo, 6(1-2): 121-138, outubro de 1995.

\title{
0 sujeito em Foucault: estética da existência ou experimento moral?
}

\author{
JURANDIR FREIRE COSTA
}

RESUMO: O artigo discute as objeções levantadas às idéias de Foucault sobre a ética do sujeito, que levariam a um descompromisso com os valores universais e princípios das democracias liberais. Discutindo as proposições de Taylor, Hochlitz, Hadot e Rorty, a resposta de Foucault se construiria a partir de uma mudança radical na imagem do sujeito e nos modos de vida relacional que, no caso da sexualidade, ao se redescreverem as categorias, colocaria em questão a atual hierarquia moral das práticas sexuais, com suas relações fixas de dominação e sujeição.

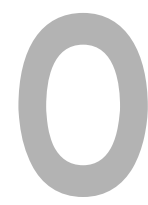

s últimos trabalhos de Foucault sobre a ética do sujeito despertaram várias objeções. Penso em retomar uma delas, procurando analisar os argumentos que a sustentam. A objeção é a seguinte: Foucault defende a idéia de uma estética da existência voltada para a auto-perfeição e auto-afirmação do sujeito. Esta estética dispensaria o compromisso com valores universais ou com os princípios humanitários das democracias liberais. Os críticos universalistas, entre os quais, Charles Taylor, Rainer Hochlitz e Pierre Hadot, enfatizam o primeiro aspecto. Alegam que Foucault se auto-engana ou se equivoca. Engana-se quando assume tacitamente valores universais que desacredita; equivoca-se quando interpreta erroneamente textos histórico-filosóficos que justificam sua teoria. Richard Rorty, representante do neopragmatismo, chama a atenção para o segundo aspecto, criticando a insensibilidade de Foucault para com os princípios e ganhos das sociedades liberais.
UNITERMOS:

Foucault, sujeito,

estética da existência, práticas e papéis sexuais, homossexualismo, sado-masoquismo.

Professor do Instituto de Medicina Social da UFRJ 


\section{A crítica universalista}

Foucault, diz Taylor, admite, com Nietzsche, que "não existe uma ordem da vida humana, ou de nossa maneira de ser, ou da natureza humana à qual possamos nos referir para julgar ou avaliar os modos de vida. Existem apenas diferentes ordens impostas pelos homens ao caos primitivo, segundo sua vontade de potência" (Taylor, 1989, p. 113). Esta tese, para o autor, se auto-refuta nos dois postulados centrais, o relativismo e a onipresença do poder. Se Foucault aceita que é "impossível fazer um julgamento sobre as diferentes formas de vida"- tese relativista - e se aceita que todas formas de vida "colocam em jogo uma imposição de poder" (p. 113), como justificar, diz Taylor, suas opções éticas? . Por que considerar a dominação e a sujeição como coisas más? Por que não se limitar meramente a constatar a vigência deste regime de ordem, sem entrar em considerações valorativas? Das duas uma: ou Foucault enuncia coisas sem sentido ou utiliza implicitamente uma moral cujos pressupostos desconhece ou tenta esconder.

Para Taylor, o segundo pólo da alternativa é o verdadeiro. Foucault não traz à superfície os fundamentos morais responsáveis por suas escolhas teóricas. Combater o poder, a dominação e a sujeição exigem a contrapartida da liberdade de recriar novos modos de subjetividade. Mas, se isto é verdadeiro, então, existem ou não valores universais na teoria foucaultiana? Pressupor que a liberdade de auto-criação é melhor do que a dominação e a sujeição, implica ou não na admissão de noções morais universalmente válidas? Taylor vai além. Afirma que Foucault quer situar-se no lugar metafísico de crítico atemporal da cultura. Isto, porém, choca-se com suas intenções genealógicas. Não se pode "adotar o ponto de vista de um observador completamente estrangeiro, como se estivesse em Sirius ou como se fosse uma alma no mito platônico da caverna: a mim de decidir se quero ser um chinês da dinastia Song, um sujeito do Hamurabi, na Babilônia, ou um americano do século vinte" (Taylor, 1989, p. 118). "Sem uma identidade prévia, continua Taylor, ninguém poderia sequer pensar em escolher" (p. 118).

Foucault, portanto, ilude-se, imaginando que é um zero identitário, flutuando acima da história ou da cultura. Sem a idéia de "vontade" como algo produzido por nossa autonomia "interior", sem os valores do humanitarismo moderno, como o desejo de preservar a vida, de satisfazer as necessidades do homem e de aliviar seus sofrimentos, sem a idéia de satisfação emotiva ou a de que "nossos sentimentos são uma das chaves para uma vida de qualidade", enfim, sem a preocupação com a "vida ordinária", e não com a contemplação, as virtudes cívicas, a honra de casta, os valores espirituais, etc., das sociedades antigas, será que Foucault poderia pensar em sua estética da existência ou ética dos prazeres? Taylor responde pela negativa, concluindo que Foucault é filho da ética ocidental, cuja genealogia quer fazer e cuja legitimidade quer negar. Uma coisa, argumenta ele, é dizer, por exem- 
plo, que a burocracia, as práticas disciplinares de sujeição, a importância desmesurada do sexo no Ocidente, etc., são itens indesejáveis na constituição de nossas identidades e moralidades. Outra coisa énegar a validade do quadro ético geral que permitiu a emergência de tais fenômenos mas também do pensamento de Foucault. Sem esta base ética, o pensador Foucault seria impensável, improvável ou impossível.

Os argumentos de Rochlitz são semelhantes, mas variam ligeiramente de rumo. Para o autor, a teoria e a prática política de Foucault "possuem um conteúdo normativo e mesmo uma normatividade virtualmente universalista, quando se referem a uma exigência de autonomia da pessoa e opõem-se ao sofrimento injusto" (Rochlitz, 1989, p. 290). Mas ele não só nega isto como não pode admitir que "as qualidades que lhe permitem escapar aos poderes tenham uma existência independente dele, inscrevendo-se na estrutura mesma da sociedade moderna, como crítica institucionalizada, espaço de liberdade e de discussão, irredutível ao sistema de poder" (p. 296). Ou seja, Foucault além de possuir uma ética virtualmente universalista condena uma estrutura social de que depende e sem a qual não teria como pensar o que pensou. A estética da existência, prossegue Rochlitz, não se opõe ao biopoder como algo que lhe é exterior. "A idéia de um prazer partilhado sem dominação é tributária das idéias modernas de igualdade, reciprocidade e nãoviolência que se desenvolveram simultaneamente ao bio-poder" (Rochlitz, 1989, p. 293) posto na mira das críticas foucaultianas.

Portanto, diz Rochlitz, a reinvenção de modos individuais de existência só é possível porque a ordem criticada permite e incentiva a diversidade, a singularidade e a pluralidade de pensamentos e estilos de vida. Foucault não vê que sua proposta de novas formas de vida é um tópico do universalismo ético da cultura a que pertence. O que significa querer fazer da "vida uma obra de arte", senão estender o projeto das elites das sociedades antigas para toda sociedade? $\mathrm{Na}$ Grécia e em Roma, a tarefa da estética da existência cabia às "minorias privilegiadas, liberadas de toda função na reprodução material da sociedade e que podiam empregar todas suas forças para realizar o refinamento de seus estilos de vida" (Rochlitz, 1989, p. 297); no programa de Foucault, deve estar ao alcance de todos. Nos dois casos, a pretensão ao universalismo é evidente, consideradas as diferenças nas imagens do sujeito. No entender de Rochlitz, Foucault propõe "um equivalente anarquizante da ética pós-convencional" como substituto do universalismo ético. Mas esta ética é somente um caso particular do universalismo (cf. Rochlitz, 1989, p. 297).

Quanto à interiorização, pergunta ele, como Foucault poderia romper com as intuições morais correntes, sem "um exame crítico da norma denunciada como um elemento no dispositivo de poder" (Rochlitz, 1989, p. 297). Ou seja, nos termos de Taylor, como fugir da idéia de autonomia, vontade interior, reflexão crítica, etc., como motor da transformação das subjetividades? Foucault, em sua formulação, não se subtrai à "exigência de interiorização". Querendo, ou não, está na órbita do sujeito cristão do dese- 
jo, do qual afirma ter-se libertado.

Para um outro autor, Hadot, Foucault utiliza indevidamente o material histórico da antigüidade, na pressa de fundamentar suas próprias crenças. Não é verdade que o pensamento estóico caucione a idéia de uma ética sem universais, assim como é incorreto ou discutível dizer que sujeito moderno está presente no pensamento cristão das origens, na figura da interiorização individualizante ou da hermenêutica do desejo. Ao utilizar a idéia de ética dos prazeres dos estóicos, Foucault oculta a distinção entre prazer e alegria, central naquele pensamento. Os estóicos elegeram a palavra alegria como foco de suas reflexões, justamente porque "recusavam-se a introduzir o princípio do prazer na vida moral" (Hadot, 1989, p. 262). Esta distinção é fundamental. A ética da alegria, e não dos prazeres, não se centrava no "eu" singular de cada sujeito. Era expressão da "melhor parte do eu", daquela orientada pelo "bem verdadeiro", de acordo com a "razão e a natureza universais". Havia, segundo este autor, um apelo ao universalismo moral nos estóicos que Foucault desprezou, em benefício de suas concepções.

No que diz respeito ao pensamento cristão, o procedimento intelectual foi quase o mesmo. De fato, os exercícios espirituais visavam à interiorização do sujeito ou à hermenêutica do desejo individual. Mas a interiorização era vista como "superação de si em direção da universalização" (Hadot, 1989, p. 267). Hadot pensa que uma estética da existência descolada de qualquer referência a valores transcendentais, poderia ser nada mais, nada menos, do que "uma nova forma de dandismo, versão fim do século XX" ( p. 267). Este é seu temor. Uma cultura de si, sem vínculos com valores universais, pode tornar-se uma questão de preferência de um ou de poucos, mas nunca recomendação moral para todos.

\section{A crítica neo-pragmática}

A crítica neo-pragmática de Rorty é de outro teor. Como os autores precedentes, ele acredita que o esteticismo de Foucault acaba indo de encontro aos objetivos da comunidade. Mas não acha que a garantia de compromisso com o bem coletivo seja a crença em valores universalmente válidos. A obra de Rorty dirigiu-se, em grande parte, à crítica do universalismo como fundamento racional das moralidades. Os argumentos que emprega podem, deste modo, servir de réplica ao que foi objetado à Foucault. Brevemente, Rorty, como Foucault, não acredita na existência de valores universais, se pela expressão se entende um conjunto de postulados morais apriorísticos e invulneráveis à revisão histórica. Mesmo concedendo que tais valores existissem, restaria aos universalistas provarem como o acesso epistêmico às entidades transhistóricas pode estar ao alcance de sujeitos históricos. Por este motivo, a seu ver, os valores tidos como necessários e atemporais, pelos universalistas, nada mais são do que os valores do humanitarismo democrático moderno metafisicamente transferidos para o domínio das entidades 
transcendentais.

Para o neo-pragmatismo, nenhum procedimento racional consistente pode afirmar a permanência empírica ou conceitual de uma mesma identidade essencial do mundo, do sujeito e da linguagem. Conhecemos contingências e não necessidades. Buscar a identidade do sujeito ou de valores morais no que é perene é uma tarefa fútil. Nenhuma de nossas crenças vem de uma fonte de sentido prévia à ação humana. A história mostrou que inúmeros candidatos ao papel fundacional não resistiram ao teste do tempo. Ou perderam completamente a plausibilidade intelectual ou retraíram-se e converteram-se em crenças opcionais, de grupos ou pessoas, como no caso das convicções religiosas. Podemos tratar certas imagens do mundo e do sujeito como universais. Mas isto quer dizer, simplesmente, que certas formas de vida nos são de tal modo familiares que não conseguimos pensar em descrições alternativas do que consideramos natural e universal. Os universais mudam quando mudam as formas de vida. Por conseguinte, tudo o que podemos fazer é aceitar a tradição ética que herdamos, procurar transformá-la ou abandoná-la por outra tradição. Não temos saída: falamos de crenças sempre do interior de outras crenças. A preferência atual é um simples produto da persuasão cultural tornada convicção. Justificamos nossas crenças porque acreditamos que são superiores à outras. Superioridade que não se funda na maior ou menor racionalidade da crença aceita - todas são racionais - mas na força performativa dos meios de transmissão da cultura de cada um.

Assim sendo, a crítica universalista a Foucault perde o sentido. Liberdade, autonomia, respeito à vida, etc., são vocábulos da prática lingüística das democracias liberais, individualistas e humanitárias e não verdades atemporais plantadas no céu das idéias desde sempre e para sempre. Quanto ao sujeito da interioridade, Rorty também dá pouca importância à esta disputa. O sujeito, no neo-pragmatismo, nada mais é do que "a rede de crenças e desejos postulada como causa interior dos atos lingüísticos". As redes são múltiplas, mutáveis, e saber quando e como teve início o "sujeito da autonomia, da vontade e da interioridade" só tem interesse, se se trata de conservar ou alterar esta descrição, em função de propósitos éticos. O problema, portanto, não é o de saber se Foucault repete, inadvertidamente, as aspirações do sujeito do desejo e da interioridade. Esta questão é secundária. Mais importante do que isto é saber se sua ética do sujeito atende ou não aos requisitos da moral liberal e democrática defendida pelo neo-pragmatismo. Rorty acha que não, e este é o centro de sua crítica. Foucault e seu sujeito levam-nos a ver os princípios da democracia liberal não só como datados, o que faz sentido, mas como caducos e opressivos, o que lhe parece inaceitável. Neste aspecto, concorda com os universalistas. Acredita, como eles, que Foucault participa da cultura do "ressentimento", ou seja, da corrente intelectual que procura negar, subestimar ou minimizar o progresso moral alcançado pelas democracias liberais do Ocidente.

Para fundar seu ponto de vista, Rorty procura retificar Foucault de 
COSTA, Jurandir Freire. O sujeito em Foucault: estética da existência ou experimento moral? Tempo Social; Rev. Sociol. USP, S. Paulo, 7(1-2): 121-138, outubro de 1995.

Nosso objetivo não é o de apresentar sistemáticamente o pensamento de Richard Rorty. Limito-me, aqui, a enviar o leitor aos estudos que mais diretamente dizem respeito ao tema discutido neste texto. Além de alguns textos do próprio Rorty, citados no trabalho, ver Murphy, 1990 e Hall, 1994;

2 Sobre Davidson, ver: Davidson, 1982, 1990, 1991a, 1991; Evnine, 1991; Ramberg, 1989; Engel, 1989 forma parecida à que utilizou para corrigir, num dado momento, seu próprio trajeto teórico ${ }^{2}$. Resumidamente, para ele, as grandes mudanças na vida política e na moralidade social coincidem com as inovações culturais. Inovação cultural é uma expressão que deve ser entendida segundo os postulados da teoria da linguagem de Donald Davidson ${ }^{2}$. Em Davidson, tanto palavras, frases e enunciados quanto crenças e desejos são teias lingüísticas causadas por fatos lingüísticos e não-lingüísticos. Os fatos não-lingüísticos são aqueles descritos como fatos físicos e os lingüísticos como palavras, enunciados ou crenças que promovam transformações nos estados mentais anteriores dos organismos humanos. A consequiência desta afirmação, à primeira vista obscura e enigmática, é a de que nem toda causa de mudança em nossas crenças provém de outras crenças e, ainda menos, de crenças fundadas em argumentos racionais com pretensão à universalidade. Em síntese, todas nossas crenças são causadas, mas nem toda causa de alterações de crenças são razões ou justificativas.

Davidson distingue, assim, causas de razões. Uma razão, ou seja, um conjunto de enunciados ou de argumentos com sentido familiar, pode ser causa de alteração de crenças. Mas um fato físico também pode ser causa de mudanças, assim como fatos lingüísticos sem sentido. É o caso do que denomina de "metáfora viva" ou simplesmente metáfora. Uma metáfora é um termo, expressão ou enunciado cujo uso ainda não foi "literalizado", ou seja, regularizado pelo hábito lingüístico corrente. É, portanto, um ato lingüístico novo, até ser usado convencionalmente, com extensão e significação familiares à comunidade competente de falantes. Não tendo sentido convencional, a metáfora sugere, solicita ou, como prefere Davidson, "intima" os sujeitos renovarem a descrição de si ou do mundo. Age, por isto mesmo, como uma causa lingüística de mudança de crenças que ainda não se tornou "justificação" aceitável da mudança.

Rorty rebate a concepção de Davidson sobre sua filosofia moral. As metáforas mais inventivas, diz ele, podem redescrever o sujeito de maneira imprevisível. E quando são historicamente felizes, funcionam como justificativas para a recriação de novos modos de vida e sistemas morais. Rorty vê na reinvenção da língua e dos estilos de vida correlatos, o principal motor da transformação cultural, ética e política das sociedades. Donde o papel que reserva aos artistas. Os artistas em geral, e os ficcionistas em particular, poetas e novelistas, são os experimentadores culturais por excelência. Em vista disso, tornaram-se os grandes artífices das subjetividades modernas. "Revolucionários utópicos, ironistas liberais" e "poetas fortes" formam a tríade dos heróis da narrativa rortyana. Todos são agentes capazes de criar novas metáforas sobre o sujeito e o mundo. Mas o ironista liberal, além disto, duvida de seus próprios vocabulários finais, comparando suas crenças e valores a outras formas de vida, e tentando produzir novos experimentos morais que possam enriquecer sua existência e a dos outros. Em outras palavras, a metaforização constante das imagens do sujeito amplia seu espectro de escolhas éticas e suas 
oportunidades de bem-estar e felicidade. Este objetivo, em sua opinião, é um efeito do Romantismo sobre a cultura ocidental. O desejo romântico de singularização do indivíduo faz com que ele deseje permanentemente redescrever-se e, nesta atividade, pode vir a criar novos valores e subjetividades, até então inexistentes.

Mas, chegado a este termo, Rorty deu-se conta de que o experimentalismo romântico tinha "um lado escuro". Quando a idiossincrasia do inventor era levada a ponto de "usar outros como o propósito de gratificações privadas; ou a utilizar mais do que permite uma justa repartição de recursos; ou quando o montante de tempo despendido na auto-criação exclui todo exercício no suporte da justiça pública; ou quando o self que criamos é um cabeçadura embotado ou um esteta arrogante, insensível à dor e à humilhação dos outros"(Hall, 1994, p. 111), nestes casos, a auto-realização tornava-se ilegítima e condenável. Propôs, então, um limite à criatividade pessoal. A atividade metafórica do poeta forte e do revolucionário utópico deveria parar onde começavam a dor e a humilhação do outro. Desprezando a distinção formal entre ético e estético, sugere uma divisão dos discursos entre os que visam a auto-perfeição e os que visam à justiça e a decência. Os enunciados dirigidos a auto-realização buscam proteger e enriquecer as experiências pessoais; os dirigidos ao bem comum, procuram atingir um justo equilíbrio entre as aspirações à vida e à liberdade de todos. A democracia liberal é a forma de vida que possibilitou e fez coexistir os dois tipos de jogos de linguagem, pela divisão do espaço social entre uma esfera pública e uma esfera privada. As duas áreas da práxis do sujeito podem, deste modo, expandir-se sem que uma venha atropelar a outra. Podemos ser, diz Rorty, "tão irracionalistas, esteticistas quanto nos agrade, desde que não venhamos a causar mal aos outros" (Rorty, 1989 , p. XIV). Inversamente, podemos criar tantas formas políticas de governo quantas sejamos capazes de imaginar, contanto que não impeçam as aspirações a auto-realização dos indivíduos. Esta a posição do ironista liberal rortyano, diante das novas metáforas.

A crítica a Foucault tem origem nesta premissa. Em seu entender, a estética da existência foucaultiana é alheia ou avessa a estes princípios. Entretanto, pergunta ele, sem os valores ou instituições da democracia liberal, Foucault teria podido criar livremente as metáforas que exprimem suas necessidades de auto-perfeição, auto-afirmação ou auto-realização? O que Foucault diz, continua, não parece endereçar-se à nenhum "nós". Ele quer "servir à liberdade humana, mas, no interesse de sua autonomia privada, tenta ser um sem-face, sem-raízes e sem-teto. Um estranho à humanidade e à história" (Rorty, 1991a, p. 195). Foucault, em suma, seria ou tenderia a ser um esteticista em busca do sublime e não do puramente belo. Ora, o êxtase do sublime pode facilmente tornar-se cego e surdo à dor do outro. Dito de outra forma, Foucault quis derivar de uma única narrativa o que é bom para um e o que é bom para todos. Conciliar numa só recomendação os dois objetivos, é, a seu ver, impossível. Anoção de estética da existência hipertrofia o valor da 
experimentação individual. Rorty rejeita esta posição. Melhor seria, portanto, propor experimentos morais que respeitem o equilíbrio entre necessidades privadas e necessidades públicas, ao modo do ironista liberal. Só assim, acredita ele, a felicidade de um não compromete a justiça devida a todos. Por desconhecer este risco, Foucault nega os avanços morais da democracia liberal, tornando-se um potencial aspirante a sacrificar a solidariedade em benefício da auto-perfeição. Cabe investigar o que de pertinente ou não existe nestas afirmações.

\section{A resposta de Foucault}

Relendo os Ditos e Escritos de Foucault sobre a genealogia da ética e a ética do sujeito, muitas das questões levantadas por seus interlocutores se esclarecem. Como afirmei antes, deixo de lado as objeções dos universalistas. Penso que a argumentação de Rorty contra a transcendentalidade dos valores é suficiente para arbitrar o litígio. Retenho a idéia do descompromisso de Foucault em relação à sua comunidade. Este, parece-me, é o denominador comum entre a crítica rortyana neo-pragmática e a crítica dos universalistas. Pergunto, de início: em que sentido pode-se falar, com propriedade, de alheamento de Foucault para com a comunidade de seus pares e seu presente histórico? Acho que Foucault, de fato, é reticente quando se trata de conceder qualquer mérito aos ideais humanitários das democracias liberais. Mas sugiro que isto se deve, em primeiro lugar, à forma como vê a complexidade das relações humanas e, em segundo lugar, aos temas que aborda. Antes de examinar com cuidado estes aspectos, qualquer alusão à pretensa omissão política ou insensibilidade de Foucault à dor e à humilhação dos outros é precipitada. Vejamos cada um dos itens em separado.

No que diz respeito às relações humanas, Foucault foi, sem dúvida, um pessimista. Embora tenha revisado a idéia de que os dispositivos disciplinares são a única matriz das subjetividades modernas, continuou a ver o impulso de dominação como uma disposição, por assim dizer, instituinte da interação entre sujeitos. Sua visão do que somos capazes de fazer uns aos outros sempre vai no sentido do pior. Em alguns trechos de entrevistas ou artigos, isto aparece de maneira inequívoca. Na entrevista Da amizade como modo de vida, dizia: "Mas a idéia de um programa e de proposições é perigosa. Desde que um programa se apresenta, ele faz a lei, é uma proibição de inventar" (Foucault, 1994b, p. 167). Em A propósito da genealogia da ética: um resumo do trabalho em curso, afirmava: "Não procuro dizer que tudo é mau, mas que tudo é perigoso(...). Se tudo é perigoso, então temos sempre qualquer coisa a fazer. Assim, minha posição não conduz à apatia, mas ao contrário à um hiper-militantismo pessimista" (Foucault, 1994b, p. 386).

O pessimismo foucaultiano, como se vê, não tem meias medidas. Mas, pergunto, isto basta para torná-lo alguém neutro quanto a valores, indiferente à comunidade de seus fellows ou virtualmente insensível à dor e à humilhação do outro? Penso que não. Freud, por exemplo, tido por Rorty 
como um "experimentador" exemplar da vida privada, era mais ou menos pessimista do que Foucault? E o próprio Rorty? Como qualificar sua hipótese sobre nossas atitudes frente ao sofrimento dos outros? Rorty não hesita em dizer que a solidariedade, a compaixão, a simpatia, etc., que podemos manifestar ao nosso próximo nem são constantes morais universais, nem estão inscritas no coração ou na razão dos humanos. Pelo contrário, reafirma a todo instante que tais atitudes éticas são instáveis e recentes. Formaram-se, no Ocidente, à duras penas, após séculos de violências e atrocidades cometidas contra os mais frágeis. Na sua ótica, sempre podemos voltar a redescrever nosso próximo como um estranho e, em virtude disto, submetê-lo às piores brutalidades, se dispusermos dos instrumentos de força ou coerção adequados. Isto é pessimismo ou otimismo? Onde começa e termina a linha que separa um do outro?

Dependendo de quem julga, Rorty poderia ser perfeitamente etiquetado de pessimista! No entanto, seus receios quanto à crueldade latente em todos nós, não o tornam, a seus olhos, indiferente aos valores democráticos, liberais e humanitários. Por que o pessimismo de Foucault seria diferente? Por que emprega a categoria de "poder" e não a de "disposição para humilhar e ferir o outro"? Mas se Rorty define humilhação como "redescrição forçada", em que isto se distingue substancialmente dos efeitos de poder sobre os indivíduos analisados por Foucault? E, afinal, se o critério pragmático para saber o que é ou não eticamente aceitável, são os resultados morais práticos e não um acordo sobre princípios transcendentais ou racionais, como ignorar o papel de Foucault na sensibilização intelectual moderna para com a dor e a humilhação do outro? Como notou Hall, poucos pensadores atuais denunciaram com tanto vigor quanto Foucault o que existe de cruel e moralmente abusivo nas relações humanas. $\mathrm{O}$ fato de não procurar justificar sua prática teóricopolítica por meio de princípios definitórios, por acaso invalida o mérito do que disse, pensou ou fez? Seus estudos sobre presídios, hospitais, hospícios, escolas, casernas, indústrias, etc., são exemplos de indiferença ou relativismo axiológico ou de engajamento na luta em favor dos humilhados e ofendidos? Foucault, considerado tudo isto, é um faceless, um homeless, ou alguém que fala por um "nós" e empresta sua voz a um "nós"?

Mas o que Rorty reprova em Foucault, principalmente, não é propriamente sua pretensa impermeabilidade à dor do outro. É seu laconismo quando se trata de elogiar as instituições liberais das democracias modernas. Também neste nível, creio, a atitude de Foucault é explicável, quando se observa os problemas por ele estudados. Foucault não pensava, como Rorty, que todos os enunciados morais reduzem-se à dicotomia do público e do privado. Certos problemas, seguramente, cabem nesta classificação; outros, não. $\mathrm{O}$ excessivo classicismo político de Rorty não lhe deixou ver o que, na cultura, rompe com estas fronteiras. É verdade, como observou Berten, que Rorty nunca pretendeu definir o público e o privado, como se fossem "essências". Sua intenção era a de utilizar uma classificação pragmaticamente operante, capaz 
de diferenciar as aspirações individuais legítimas das ilegítimas, no que diz respeito às aspirações do outro (cf. Berten, 1994). No entanto, mesmo feita a reserva, discussões culturais recentes mostraram que fatos tidos como exclusivos da vida privada podem ter relevância pública e vice-versa. Fraser notou, por exemplo, que aquilo que Hannah Arendt chamou de social tem, ao mesmo tempo, uma dimensão privada e uma pública. A vida familiar, a sexualidade, a questão da mulher, a educação sentimental das crianças, as tecnologias de saúde, as práticas de cuidado do corpo, etc., são casos deste tipo. Aliás, o próprio Rorty, respondendo à Alexander Nehamas, dizia que "público" e "privado" podem ter significações variáveis (Rorty,1992, p. 211-212). Citando duas situações conflitivas, apontava a família como sendo o referente do "privado" em um caso e o referente do "público", em outro.

Mas se é assim, por que não considerar que a especificidade dos assuntos discutidos por Foucault pode dispensar tal divisão, sem prejuízo do respeito ao sofrimento do outro? Em última instância, penso que o que Rorty não aceita é a redescrição do sujeito e da vida relacional proposta por Foucault. Esta redescrição, em minha opinião, não afeta em nada a "mínima moral" defendida por Rorty. Porém, pode parecer uma "redescrição forçada" para quem acredita que as instituições e os problemas com que lidamos estão em ordem, bastando alterar, aqui e ali, o que anda enferrujado ou fazendo muito barulho. Como exemplo, dou o caso da sexualidade. Foucault acreditava que só uma virada radical na imagem de sujeito e dos modos de vida relacional poderia desfazer certos impasses criados pela atual hierarquia moral das sexualidades. Para efeito de exposição, tomo as duas questões em separado - a da imagem do sujeito e a da imagem da vida relacional - para analisá-las em detalhes.

A mudança na imagem do sujeito defendida por Foucault é conhecida. Corresponde à noção de estilo de vida ou estética da existência baseada numa ética dos prazeres e não do sexo. Dando ênfase aos prazeres e não ao sexo, os sujeitos poderiam reinventar-se, sem recorrer às identidades criadas pelo sistema de nominação preconceituoso. Sexo, hermenêutica do desejo, obsessão pela verdade de si, identidades sócio-sexuais fixas, etc., são termos do mesmo vocabulário moral articulado aos dispositivos de sexualidade. A este propósito, Foucault dizia: "Outra coisa de que é preciso desconfiar é da tendência para trazer a questão da homossexualidade para o problema do "Quem sou eu?", “Qual o segredo de meu desejo?". Talvez fosse melhor perguntar: "Que relações podem ser estabelecidas, inventadas, multiplicadas, moduladas, por meio da homossexualidade". O problema não é o de descobrir em si a verdade de seu sexo, mas o de usar, de agora em diante, de sua sexualidade para chegar à multiplicidade de relações. É, sem dúvida, aí que está a verdadeira razão pela qual a homossexualidade não é uma forma de desejo mas alguma coisa de desejável. Nós devemos, então, dedicar-nos a tornarmonos homossexuais e não a nos obstinar em reconhecer que somos homossexuais" (Foucault, 1994b, p. 163). Mais adiante, na mesma entrevista, reiterava: 
"Cabe a nós avançar numa ascese homossexual que nos fizesse trabalhar sobre nós mesmos e inventar, não digo descobrir, uma maneira de ser ainda improvável" (p. 165).

Em outra entrevista, comentando os livros de John Boswell e Karl Dover sobre o homossexualismo, afirmava: "É preciso usar de sua sexualidade para descobrir, inventar novas relações. Ser gay é ser se tornando [c'est être en devenir] e, para responder à sua questão, acrescentaria que é preciso não ser homossexual mas insistir em ser gay" (Foucault, 1994b, p 295). Depois, na entrevista intitulada $O$ triunfo social do prazer sexual: uma conversação com Michel Foucault, dizia: "Fazer escapar o prazer da relação sexual do campo normativo da sexualidade e suas categorias; fazer, por esta mesma razão, do prazer o ponto de cristalização de uma nova cultura, é, acredito uma abordagem interessante"(p. 309). Por fim, em Entrevista de Michel Foucault confirmava os pontos de vista anteriores: "Foi só a partir do momento em que o dispositivo de sexualidade implantou-se efetivamente, quer dizer, no momento em que um conjunto de práticas, instituições e conhecimentos fez da sexualidade um domínio coerente e uma dimensão absolutamente fundamental do indivíduo, foi neste momento preciso, sim, que a questão "Que ser sexual você é? "tornou-se inevitável(...) Se bem que do ponto de vista tático importa num dado momento poder dizer 'Eu sou homossexual', é preciso, a meu ver, a longo prazo e no quadro de uma estratégia mais vasta colocar questões sobre a identidade sexual. Não se trata, então, de confirmar sua identidade sexual, mas de recusar a injunção de identificação à sexualidade, às diferentes formas de sexualidade. É preciso recusar satisfazer a obrigação da identificação por intermédio e com a ajuda de uma certa forma de sexualidade" (Foucault, 1994b, p. 662).

Nas entrevistas fica claro o objetivo de Foucault. Só uma redescrição inédita das subjetividades poderia destronar o sexo-rei e sua corte de identidades sexuais. Enquanto a auto-realização ou a auto-perfeição privada curvarem-se ao sujeito sexual dominante, poucas chances existem de que venhamos a imaginar um modo de vida sem a violência do preconceito. Ora, este modelo do sujeito sexualmente descentrado e voltado para uma ética ou estética dos prazeres, não tem lugar no imaginário de Rorty. $\mathrm{O}$ ironismo por ele recomendado parece assustar-se com as metáforas de Foucault. Em sua ética, não obstante seus protestos, tudo o que deve ser feito é o que vem sendo feito. Assim, falando a respeito do tema das escolhas morais privadas, afirma que "intelectuais românticos, religiosos místicos, fetichistas sexuais" (Rorty, 1991a, p. 197) podem ter direito a buscar sua auto-realização, desde que respeitem o limite do público. Em outro artigo, mostrando a meta liberal de convívio humano diz: "para tornar os Brancos mais amáveis com os Negros, os machos com as mulheres, (...) ou os heterossexuais com os homossexuais..." etc. (Rorty, 1994, p. 27). Ou seja, quando fala de conflitos, Rorty deixa de lado a contingência do sujeito e da linguagem e toma como perenes as identidades instituídas de raça, sexo, gênero etc. 
Ora, é justamente isto que Foucault procura redescrever. Mas, em sua ficção de um mundo novo, a vida relacional transborda o quadro institucional estabelecido. Foucault não cansa de repetir: não basta "liberar" o que se supõe sufocado ou reprimido. O próprio reprimido e sufocado foi produzido pelos dispositivos disciplinares. A miséria sexual, dizia ele, é produzida como o capitalismo produz miséria econômica. Ou seja, não basta dar pão sexual aos famintos; é preciso que deixemos de produzir um mesmo tipo de fome. $\mathrm{Na}$ famosa entrevista Não ao sexo rei, Foucault observava: "Um movimento se desenha hoje que parece subir a ladeira do 'sempre mais sexo', 'sempre mais verdade do sexo' à qual séculos nos haviam fadado; trata-se, não digo de redescobrir, mas simplesmente de fabricar outras formas de prazeres, de relações, de coexistências, de ligações, de amores, de intensidades" (Foucault, 1994a, p. 261). Na entrevista mencionada, Da amizade como modo de vida, volta ao tema: "Aquilo para o que se orienta os desenvolvimentos do problema da homossexualidade é o problema da amizade. (...) Homens de idade notavelmente diferentes, que código terão eles para se comunicarem entre si? Eles estão um em face do outro sem armas, sem palavras convencionais, sem nada que possa reassegurá-los sobre o sentido do movimento que os leva um para o outro. Terão que inventar de $\mathrm{A} a \mathrm{Z}$ uma relação ainda sem forma e que é a amizade: quer dizer a soma de todas as coisa pelas quais pode-se dar prazer um ao outro" (Foucault, 1994b, p.163-164). Em outra passagem da mesma entrevista é dito: "Esta noção de modo de vida me parece importante. Será que não seria preciso introduzir uma diversificação outra que não aquela devida às classes sociais, diferenças de profissão, de níveis culturais, uma diversificação que seria também uma forma de relação e que seria "o modo de vida". Um modo de vida pode ser partilhado por indivíduos de idade, estatuto e atividade sociais diferentes. Pode dar lugar à relações intensas que não se parecem a nenhuma daquelas que são institucionalizadas e me parece que um modo de vida pode dar lugar a uma cultura e a uma ética. Ser gay é, creio, não se identificar aos traços psicológicos e às máscaras visiveis do homossexual, mas buscar a definir e a desenvolver um modo de vida" (Foucault, 1994b, p. 165).

Este modo de vida, contudo, pede uma rede institucional outra que não a conhecida. Na entrevista $O$ triunfo social do prazer sexual: uma conversação com Michel Foucault indícios deste modo de vida são sugeridos: "Vivemos em um mundo relacional que as instituições empobreceram consideravelmente. A sociedade e as instituições que constituem sua ossatura limitaram a possibilidade de relações porque um mundo relacional rico seria extremamente complicado de gerir. Devemos bater-nos contra este empobrecimento do tecido relacional. (...) Tomemos, por exemplo, as relações de amizade. (...) Elas desempenhavam um papel considerável, mas havia toda uma espécie de enquadramento institucional flexível - mesmo se, por vezes, era coercitivo - com um sistema de obrigações, de tarefas, de deveres recíprocos, uma hierarquia entre amigos, e assim por diante. (...) Quando você 
COSTA, Jurandir Freire. O sujeito em Foucault: estética da existência ou experimento moral? Tempo Social; Rev. Sociol. USP, S. Paulo, 7(1-2): 121-138, outubro de 1995.

lê um testemunho de dois amigos desta época, você se pergunta sempre o que acontecia realmente. Faziam eles amor juntos? Tinham uma comunidade de interesses? Nenhuma das duas coisas ou as duas?" (Foucault, 1994b, p. 309310). Continuando, diz Foucault: "Em realidade, a vida de solidão à qualé condenado o celibatário é, freqüentemente, o efeito do empobrecimento das possibilidades relacionais em nossa sociedade, onde as instituições tornam exangues e necessariamente raras todas as relações que se poderia ter com um outro e que poderia ser intensas, ricas, mesmo se fossem provisórias, mesmo e sobretudo se não tivessem lugar nos laços do casamento" (Foucault, 1994b, p. 311).

Em outra passagem de suas intervenções, diz: "Que em nome do respeito aos direitos do indivíduo, deixemos que ele faça o que quiser, tudo bem. Mas se o que se quer fazer é criar um novo modo de vida, então a questão dos direitos do indivíduo não é pertinente. Com efeito, vivemos num mundo legal, social, institucional, onde as únicas relações possíveis são extremamente pouco numerosas, extremamente esquematizadas, extremamente pobres. Existe, evidentemente, a relação de casamento e as relações de família, mas quantas outras relações poderiam existir, poderiam encontrar seus códigos não nas instituições mas em suportes eventuais? Isto não acontece em absoluto" (Foucault, 1994b, p. 309).

Resta perguntar em que o desejo de criar um tecido relacional mais rico, intenso, plural, que ofereça novas possibilidades de satisfação emocional pode ser contrário à consideração pela dor e sofrimento do outro? Em nada, penso. Obviamente, Rorty poderia replicar que esta crítica aos espaços institucionais poderia violentar as convicções dos que aceitam os limites morais do estado de coisas existentes. Como observou Visker, ele crê que "a maioria das pessoas não deseja ser redescrita" e "quer ser levada à sério nos seus próprios termos, ou seja, na maneira como é como fala" (Visker, 1994, p. 281-282). A "redescrição freqüentemente humilha", "sugerindo que o eu e o mundo" de quem está sendo redescrito "é fútil, obsoleto e vão" (Rorty, 1989, p. 89-90). Mas isto aplica-se ao próprio Rorty! A distinção entre o "ironista" indiferente ao outro e o "ironista liberal rortyano" atento ao outro, não pode ser feita com base nos riscos de "humilhação", presentes em toda redescrição. A distinção entre o indiferente e o sensível ao sofrimento do outro, passa pela defesa que o segundo faz do "valor do respeito ao sofrimento alheio". Porém, em que sentido pode-se dizer que Foucault mostrou-se indiferente à idéia de sofrimento? Em nenhum, sugiro. Como prova, tomo seus depoimentos sobre o sado-masoquismo, figura da sexualidade, onde o sofrimento é, mais do que em outras, problematizado.

Falando a respeito do sado-masoquismo dizia: "Eu vou arriscar a hipótese seguinte: numa civilização que, durante séculos, considerou que a essência da relação entre duas pessoas residia no fato de saber se, sim ou não, uma das duas partes ia ceder à outra, todo o interesse e toda a curiosidade, toda audácia e a manipulação de que dão prova as partes em questão sempre 
visaram à submissão do parceiro afim de dormir com ele. (...) O sado-masoquismo não é uma relação entre aquele (ou aquela) que sofre e aquele (ou aquela) que infringe sofrimento, mas entre um senhor e a pessoa sobre a qual se exerce sua autoridade. $O$ que interessa aos adeptos do sado-masoquismo é o fato de que a relação é, ao mesmo tempo, submetida às regras e aberta. Ela parece um jogo de xadrez, onde um pode perder e outro ganhar. $\mathrm{O}$ senhor pode perder (...) se se revela incapaz de satisfazer as necessidades e as exigências de sofrimento de sua vítima. Do mesmo modo, o escravo pode perder se não consegue superar ou se não suporta superar o desafio lançado pelo seu mestre. Esta mistura de regras e abertura tem por efeito uma intensificação das relações sexuais, introduzindo uma novidade, uma tensão e uma incerteza perpétuas, de que é exemplo a consumação do ato. $O$ objetivo é assim de utilizar cada parte do corpo como um instrumento sexual" (Foucault, 1994b, p. 331-332).

Em outro lugar, voltando ao assunto, diz ele: "O sexo não é uma fatalidade; é uma possibilidade de aceder a uma vida criativa. (...) Eu não penso que este movimento [a chamada cultura sado-masoquista] de práticas sexuais tenha nada a ver com a atualização ou a descoberta de tendências sado-masoquistas profundamente enterradas em nosso inconsciente. Penso que o s/m é muito mais do que isso. É a criação de novas possibilidades de prazer, que não tínhamos imaginado antes. A idéia de que o $s / m$ está ligado a uma violência profunda; que sua prática é um meio de liberar esta violência, de dar livre curso à agressão é uma idéia estúpida. Sabemos muito bem que o que estas pessoas fazem não é agressivo; que elas inventam novas possibilidades de prazer, utilizando certas partes bizarras de seus corpos erotizando este corpo. Penso que temos neste caso uma espécie de criação, da qual uma das principais características é o que chamo a dessexualização do prazer. A idéia de que o prazer físico provém sempre do prazer sexual e a idéia de que o prazer sexual é a base de todos os prazeres possíveis, isto, penso, é verdadeiramente qualquer coisa de falso. O que as prática $s / m$ nos mostram é que podemos produzir prazer a partir de objetos muito estranhos, utilizando certas partes bizarras de nosso corpo, em situações muito inabituais (...). A possibilidade de usar nosso corpo como fonte de prazer possível de uma multidão de prazeres é algo de muito importante. Se consideramos, por exemplo, a construção tradicional do prazer, constatamos que os prazeres físicos, ou prazeres da carne, são sempre a bebida, a comida e o sexo. É aí que se limita nossa compreensão dos corpos, dos prazeres. (...) O jogo s/m é muito interessante porque, embora seja uma relação estratégica, é sempre fluido. Existem papéis, é claro, mas cada um sabe que estes papéis podem ser invertidos. Por vezes, quando o jogo começa, um é o mestre e o outro o escravo e, no fim, quem era escravo tornou-se mestre. (...) Este jogo estratégico é muito interessante, enquanto fonte de prazer físico. Mas não diria que constitui uma reprodução, no interior da relação erótica, da estrutura de poder. É uma encenação das estruturas de poder por um jogo estratégico capaz de 
produzir um prazer sexual e físico" (Foucault, 1994b, p. 735-746).

Com a longa citação, não penso em caucionar, ponto por ponto, a explicação dada por Foucault ao sado-masoquismo. Concordo, no entanto, com sua tentativa de desmantelar uma categoria pretensamente homogênea de "seres sexuais" inventadas no século XIX, que teriam algo em comum que seria a "sado-masoquistidade" de todos os sado-masoquistas. A citação visa mostrar que, para ele, a condição de aceitação do sado-masoquismo é sua total redescrição. Redescrição que rompe com imagem oitocentista que temos do fenômeno e que o aproxima das práticas dos prazeres ou práticas sexuais correntes na nossa cultura. Em primeiro lugar, nesta interpretação, o fundamento do sado-masoquismo não é o sofrimento e sim o prazer físico que pode ser sexual ou não. Em segundo lugar, o deslocamento do prazer, do exclusivo campo da sexualidade, permite a encenação do que Foucault entende como sendo desmontagem das relações fixas de dominação e sujeição, presentes no ato sexual. Quem manda e quem obedece; quem é passivo e quem é ativo, são papéis reversíveis na versão foucaultiana do sado-masoquismo.

É possível que, para muitos, psicanalistas inclusive, o sado-masoquismo de Foucault tenha algo de angelical. Mas este é o coração do problema. Um metafísico, na terminologia de Rorty, diria que existe uma verdadeira natureza do sado-masoquismo que Foucault tenta mascarar, dourando a pílula, em favor da própria teoria. Um ironista descomprometido com sua comunidade, limitar-se-ia a defender o direito de cidade do sado-masoquismo, sem maiores preocupações com a imagem que a maioria das pessoas tem do que representa gozar com a humilhação moral ou com sofrimentos físicos. Foucault, entretanto, justifica sua opinião, criando uma versão compatível com as exigências éticas de respeito à dor e ao sofrimento do outro. Procura fazer dos adeptos do sado-masoquismo não só "um de nós", mas "alguns dos melhores dentre nós". Ao condenar. por exemplo, o estupro, a necrofilia e a moral grega dos eros e afrodisia, deixa claro que o sofrimento e a dominação dos sujeitos é aquilo reprova e que não imagina que possa ser aceito.

Onde estaria, então, seu descompromisso com credo moral básico de seu tempo e de sua comunidade? O que ele faz, por exemplo, no caso do sado-masoquismo, é desconstruir a descrição médico-sexológica do século XIX, propondo uma outra. O que ele faz é criar uma nova metáfora que nos leva a duvidar de nossas crenças e a perguntar: por que acreditar na versão de Kraft-Ebing e não na sua? Será que existe, de fato, um "sado-masoquismo comum" à todos os sado-masoquistas? E se, em vez de carimbar pessoas com este rótulo infame, pudéssemos redescrever esta prática como uma "encenação reversível" do jogo da dominação/submissão, passividade/atividade, deslocando o sofrimento físico de seu papel de fim para o de meios com vistas a outros fins? Neste caso, por que horrorizar-se com o sado-masoquismo, nós que convivemos, entre bocejos e risadas, com lutas de boxe, viciados em exercícios físicos, pancadarias em estádios de futebol, programas de calouros em domingos televisivos, etc. Em todos estes casos, e em muitos outros, a excita- 
COSTA, Jurandir Freire. O sujeito em Foucault: estética da existência ou experimento moral? Tempo Social; Rev. Sociol. USP, S. Paulo, 7(1-2): 121-138, outubro de 1995.

ção física com o sofrimento é patente. Mas nem por isso construímos identidades sócio-sexuais ou sócio-físicas dos praticantes “destes esportes"! O escândalo do sado-masoquismo não é o sofrimento; é sua vinculação ao sexo. Foucault não só procura desvincular a relação de necessidade entre um e outro, como mostra que, deixando de acreditar na verdade do sujeito sexual, podemos pensar em relações humanas onde o "referente do pronome nós", como exige Rorty, seja sensivelmente ampliado.

Finalizando, penso que Rorty entendeu mal ou intimidou-se com a imaginação de Foucault. Não pôde ver que, num certo sentido, a démarche foucaultiana é mais rortyana do que Rorty poderia prever. Foucault não me parece nenhum candidato à crueldade. Parece-me, isto sim, um dos últimos revolucionários utópicos de nosso presente histórico. Pertence a linhagem dos Marcuses, sem a crença ingênua "na boa natureza do sexo" e nas virtudes universais da "razão estética". Não por acaso, respondendo à questão de um entrevistador - qual é a solução? - disse: "Devemos começar por reinventar o futuro, mergulhando em um presente mais criativo. Deixemos cair a Disneylândia e pensemos em Marcuse"(Foucault, 1994a, p. 678).

Nada mais pragmático; nada mais "humanamente útil".

Recebido para publicação em julho/1995

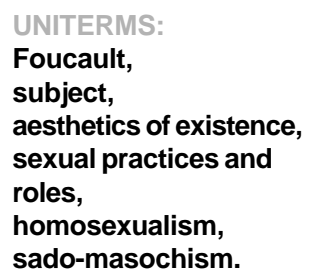

ABSTRACT: The article discusses the objections taken to Foucault's ideas about the subject's ethics which would lead to an absence of compromise with universal values and principles of the liberal democracies. Discussing Taylor's, Hochlitz's, Hadot's and Rorty's propositions Foucault's answer would be formulated based on a radical change in the subject's image and in the ways of building up relations which, in case of sexuality, as the categories are re-defined, would question the actual moral hierarchy of sexual practices with its fixed domination and subjection relationships.

\section{REFERÊNCIASBIBLIOGRÁFICAS}

BERTEN, André. (1994) Sur la distinction du public et du prive. Entre lês libéraux et communautariens. In: RORTY, Richard. Ambiguïtés et limites du postmodernisme. Organizado por G. Hottois e M. Weyenbergh. Paris, Vrin. p. 185-205. 
DAVIDSON, Donald. (1982) Paradoxes of irrationality. In: WolHeIm, Richard \& Hopkins, James (eds.). Philosophical essays on Freud. Cambridge, Cambridge University Press. p. 289-305.

. (1990) The structure and content of truth. The Journal of Philosophy, Vol. LXXXVIII, n 6, June: p. 279-328.

. (1991a) A Coherence Theory of Truth and Knowledge In: MALCHOWSKY, Alan (ed.). Reading Rorty. Oxford, Basil Blackwell. p. $120-139$.

. (1991b) Inquiries into truth \& interpretation. Oxford, Oxford University Press.

Engel, Pascal. (1994) Davidson et la philosophie du langage. Paris, PUF.

EvnINE, Simon. (1991) Donald Davidson. Stanford, Stanford University Press.

Foucault, Michel. (1994a) Dits et écrits - 1954-1988. Vol. III, 1976-1979. Paris, Gallimard.

. (1994b) Dits et écrits - 1954-1988. Vol. IV, 1980-1988. Paris, Gallimard.

FRASER, Nancy. (1990) Solidarity or singularity? Richard Rorty between romanticism and technocracy. In: MALCHOWSKY, Alan (ed.). Reading Rorty. Oxford, Basil Blackwell. p. 303-322

Hadot, Pierre. (1989) Refléxions sur la notion de "culture de soi". In: . Michel Foucault - Philosophe. Paris, Seuil. p. 261-269.

Hall, David L. (1994) Richard Rorty - Prophet and poet of the new pragmatism. New York, State University of New York Press.

MurPhy, John P. (1990) Pragmatism - From Peirce to Davidson. Boulder/ San Francisco/Oxford, Westview Press.

Rochlitz, Rainer. (1989) Esthétique de l'existence. In: . Michel Foucault - Philosophe, Paris, Seuil. p.288-300.

RAMBERG, Bjorn. (1989) Donald Davidson's philosophy of language. Oxford, Basil Blackwell.

RoRTY, Richard. (1989) Contingency, irony, and solidarity. Cambridge, Cambridge University Press.

. (1991a) Objectivity, relativism, and truth - philosophical papers. Vol. 1. Cambridge, Cambridge University Press.

. (1991b) Essays on Heidegger and others - philosophical papers. Vol. 2. Cambridge, Cambridge University Press.

. (1992) Réponse à Alexander Nehamas. In: Bouveresse, Jacques. Lire Rorty - Le pragmatisme et ses conséquences. Paris, l'Éclat. p. 213-223.

. (1994) L'espoir au lieu du savoir. Paris. 
COSTA, Jurandir Freire. O sujeito em Foucault: estética da existência ou experimento moral? Tempo Social; Rev. Sociol. USP, S. Paulo, 7(1-2): 121-138, outubro de 1995.

TAYLOR, Charles. (1989) Foucault, la liberté, la vérité, In: Michel Foucault - Lectures critiques. Bruxelles, Éditions Universitaires. p. 85-121.

VISKER, Rudi. (1994) Garder l'être. Entre ironie et finitude, In: RORTY, Richard. Ambiguïtés et limites du postmodernisme. Organizado por G. Hottois e M. Weyenbergh. Paris, Vrin. p. 275-297. 